\title{
Response to Data on Hungarian Early Neolithic graves by Bánffy et al
}

\author{
Journal of Human Genetics (2012) 57, 470-471; doi:10.1038/jhg.2012.64; published online 7 June 2012
}

Concerns (Bánffy et al. ${ }^{1}$ comments only) have recently been raised on Neolithic remains used in Guba et al. ${ }^{2}$ study in connection with their classification and age determination. In the first place, we note that '6000 years younger' was not a correct description in a title because c. 2000-yearold human remains were still not 'young' at all and they should have mentioned, for example, 'earlier dating' or similar grammatical expression according to the criteria of science writers. We also note before in-depth answering of their comments that samples were classified by them in a misleading way because it seemed for the readers that the whole basis of sampling had been confused. We here pointed that the commenter's statement on dating was not in contrary with our study, which was one of the pioneers to dig out genetic data from this region as well as a sole study from Hungary. The genetic gap, including N9a occurrence, is still valid until more mutation frequency data are provided from more recent or even modern human populations. In fact, at this initial stage of ancient molecular anthropology of a key region in Neolithisation, it is important to emphasise that the available collection for ancient DNA extraction is crucial for effective research. In experience, only $10-15 \%$ of the Neolithic remains analysed contain efficiently extractable DNA, which determines the real limitation of such kind of population genetic studies.

The dating of the remains was based on some verified archaeological publication, namely, Tibor Paluch, archaeologist at the Móra Ferenc Museum in Szeged, Hungary, publishing a comprehensive list of the human remains dated to $\mathrm{KSC}$ in the Carpathian Basin where the grave No. 8 from the site Szakmár-Kisülés was listed among KSC remains, from Table 2 in Paluch. ${ }^{3}$ The graves 20 and 22 from the site Szarvas 23 have been published well before (with the characteristic haplotype for N9a!) as KSC remains based on ${ }^{14} \mathrm{C}$ dating in Burger et al. ${ }^{4}$

However, before Guba et al., ${ }^{2}$ our initial data had also been published in Anthropologie (Brno) in Guba et al. ${ }^{5}$ (available in 2010 not in PubMed search, but at Google Scholar Search!). In that publication, basics of N9a polymorphism discovery were described, providing relevant time for the concerns to deal with the modified description of the dating of the Neolithic samples analysed. Until the end of our completed publication process, no attempt for that was made, raising further questions. One of that would be why they were satisfied with the re-evaluation of the dating of the samples used only in our study instead of an extended archaeological and radiocarbon study of the whole region. That would have been useful to get clearer information about these complex archaeological sites.

If one accepts the misdating, several queries still need to be taken into consideration. Putative Sarmatians are known about their costum to wrap corpses in leather sheets. So acids dissolved in fluids of the grave usually seriously affect the preservation of their ancient DNA content. In that case, we can only conclude that good or better preservation of bone DNA cannot be expected from Sarmatian remains at all! Moreover, in their archaeological approach these authors stated that horse remains and Sarmatian dated potteries were found in some graves. In case of the proper archaeological approach, it would be simple to see that their comment refered to their 'wishful thinking' only, in connection with their new dating. Several remains from the same sites were dated with a ${ }^{14} \mathrm{C}$ method (Table 1) resulting in a Neolithic classification, which is now widely available upon these facts, and for a contrary they provided only some potteries dated to the Sarmatians found in those graves. However, archaeologists should also refer to the good examples of consecutive usage of burial sites during prehistory and history. Even if bones were somehow misdated, from their pure data, there was no direct evidence for bones directly bounded to those certain potteries only at a first nonpeer-reviewed glance, because there would be chances for other non-Sarmatian explanations as well. Either these misdated individuals lived at the same time with Sarmatians or just were consecutively stealing or taking potteries from them in battles, and so on, the outcome was the same. And that raises two extra hypotheses: (1) despite the radiocarbon data of some graves they were misdated to that new age but still non-Sarmatians (2) coming from an even later period with keeping Sarmatian potteries.

What is more, statistical necessity is valid for archaeology as well, and if they included a few misdated individuals only, the whole theory could not be rebuilt upon them. We cannot assume that they knew about it or just wanted to extract novelty from our results by a 'watching a single tree in a forest with missing information about the whole habitat of interest' approach. This also indicated for researchers in general, before criticising others' point of view, it would be necessary to be careful at the evaluation of the new data! Somehow it would explain why it was so difficult to communicate in a non-peerreviewed way or without the in-depth analysis of archaeological evidences of our own!

Therefore, their concerns should have been raised for the archaeologists dealing with the Neolithic transition, because we did not draw any conclusion from the limited available data set on the Neolithization process itself. More extended study is seeked for in-depth analysis of the polymorhic pattern as a function of prehistoric time to draw a picture on the polimorphic background of the Neolithic transition in this region. The described 
Table $1{ }^{14} \mathrm{C}$ dating of the bone remains from archaeological sites covered in Guba et al. study based on Hertelendi et al. ${ }^{6}$

\begin{tabular}{ll}
\hline Name of locality & Archaeological period \\
\hline Vörs, Máriaasszony sziget, object no. 52 & Starčevo culture, Neolithic (cc.8000BP) \\
Szarvas 23, grave 20a & Körös culture, Neolithic (cc.7500BP) \\
Endröd 6, grave 1 & Körös culture, Neolithic (cc.7500BP) \\
Szarvas 8, grave 2/5 & Körös culture, Neolithic (cc.7500BP) \\
Szakmár-Kisülés, grave 8 & Körös culture, Neolithic (cc.7500BP) \\
Füzesabony, Gubakút, grave 9 & ALP, Neolithic (cc.7000BP) \\
Mezökövesd, Mocsolyás, grave 25 & ALP, Neolithic (cc.7000BP)
\end{tabular}

In all cases, dating of the remains is given for a site analysed, which includes a part of the ones given in Guba et al. ${ }^{2}$ Remains used in our study were marked for the period of their archaeological sites as also given in Guba et al. ${ }^{5}$ asee also Burger et al. ${ }^{4}$

genetic gap should be approached horizontally to clear up the differences of genetic pattern of the polymorphisms of mtDNA determined from KSC and ALP remains or their subsequent relatives. Dating and geographical distribution should match the strict criteria of the ancient DNA extraction in this research. That is why molecular anthropologists should rely on the available number of remains and the archeological individuals provided.

If we do still accept a Sarmatian interpretation of remains analysed, an even more evident genetic gap can be proven. Regarding, even the title of the publication is still exactly valid as given in Guba et al. ${ }^{2}$ Then N9a would be missing from the Neolithic but consecutive Alföld populations beared it. However, it was not present in some modern human populations of Carpathian Basin analysed up till now and we still needed to examine the modern human populations to extend the validity of the genetic gap theory. Their haplogroup revision as provided in their comment was not acceptable, either, with their limited data. Hence, it would be too early to pretell the final outcome, but it is important to note that these comment writers cannot see the consequences of their own statements, because comparison of Neolithic and Sarmatian with the recent available human mitochondrial mutation frequencies of the region provided the more obvious discontinuity in N9a mutations instead of homogenity as explained here. It would be the case between the Neolithic and the Sarmatians and between the Sarmatians and the modern ones. Researchers interested in it only need to collect more statistical evidences for the reliable remains to support this theory.

However, theoretical science is a free knowledge collecting process. If researchers are not willing to incorporate non-peerreviewed ambigous matters, no forces and warning from the supporters of the other opinion are obligatory to use that in the evaluation of the final results to build acceptable theories. As soon as the new data are obvious, they would be incorporated in the modified knowledge in a peer-reviewed way, instead of critics on others' research. To this, always some searches after the uncovered evidences come, resulting in data sets for the new discovery. Bearing this in mind in our research, we were in the lucky and very useful situation to find relevant differences in the genetic background, mainly in the occurrence of N9a, which helped us to draw an initial picture of the Carpatian Neolithic transition.

However, one cannot find always peerreviewed publications on the exact dating of remains, so as far as we can seriously concern this type of data set from that, we cannot draw a clearer picture of the Neolithic transition until (1) more comparisons with recent populations represented by more archaeological remains are made (2) they evaluate their data in a peer-reviewed way to make molecular anthropologist trust in their exact dating and continuous changes in the finer time reconstruction. Although independent repetition of these experiments in another laboratory was also suggested as a solution for that task, we have to note that it was only a 'wishful thinking' again. Expecting in advance only the confirmation of polymorphisms results would not be wise in such complicated experimental system. When independent experiments provided new non-confirming data, the previous data, regarding their usefulness, must have not been neglected at all. In this way, repeating experiments in several laboratories or using other mitochondrial and/or nuclear markers would be necessary as consecutive tasks to the final confirmation of our results, alongside with confident extended ${ }^{14} \mathrm{C}$ data. So, they should not expect from our laboratory to solve the whole problem alone, and we are now curious why they are so keen to concentrate so much on our work only! Instead of concentrating hypotethic comments, they would start one part of this exhaustive work giving more clear solution with being more cooperative. Organisation with several laboratories, similarly to Genographic project is under way, involving our laboratory to collect even more useful data. One interested in this important and interesting research can expect more clear understanding from the normal way of the extension of scientific knowledge!

Just after all these, with molecular and archaeological studies in synthesis with geographical distribution can we help out genetics of the Carpathian Basin from its initial state. Following Burger's Central-European studies, ${ }^{4}$ our study is still the only one fruitful to explain a part of this important question from an important Neolithic region otherwise up till now uncovered.

\section{ACKNOWLEDGEMENTS}

We thank Ildiko Pap for her fine help at discussing the comment.

Tamas Zeke and Zsuzsanna Guba

Laboratory of Molecular Anthropology, Hungarian Natural History Museum, Budapest, Hungary

E-mail: gubazsuzs@yahoo.com

1 Bánffy, E., Brandt, G. \& Alt, KW. 'Early Neolithic' graves of the Carpathian Basin are in fact 6000 years younger-Appeal for real interdisciplinary between archaeology and ancient DNA research. J. Hum. Genet. 57, 467-469 (2012).

2 Guba, Z., Hadadi, É., Major, Á., Zeke, T., Furka, T., Juhász, E. et al. HVS-I polymorphism screening of ancient human mitochondrial DNA provides evidence for N9a discontinuity and East Asian haplogroups in the Neolithic Hungary. J. Hum. Genet. 56, 784-796 (2011).

3 Paluch, T. A Körös-Starcevo kultúra temetkezései. in Hungarian/-Yearbook of the Jósa András Museum in Nyíregyháza, XLVI, 23-51 (2004).

4 Burger, J., Kirchner, M., Bramanti, B., Haak, W. \& Thomas, M. G. Absence of the lactase-persistenceassociated allele in early Neolithic Europeans. Proc. Natl Acad. Sci. USA 104, 3736-3741 (2007).

5 Guba, Z., Pap, I. \& Zeke, T. Ancient mitochondrial DNA polymorphisms from human Neolithic sites in the Carpathian Basin. Anthropologie 47, 57-67 (2009).

6 Hertelendi, E., Svingor, É., Raczky, P., Horváith, F. Futó, I. \& Bartosiewicz, L. Duration of tell settlements at four prehistoric sites in Hungary. Radiocarbon 40, 659-667 (1998) 